\title{
PENINGKATAN KUALITAS PEMBELAJARAN MELALUI E-LEARNING
}

\author{
Elsy Zuriyani \\ Balai Diklat Keagamaan Palembang \\ elsyzuriyani@gmail.com
}

Diterima: 3 Maret 2020 | Disetujui: 13 April 2020 | Dipublikasikan: 30 Juni 2020

\begin{abstract}
Abstrak
Peningkatan kualitas pembelajaran terus ditingkatkan dan dipertahakan dengan mengikuti perkembangan zaman. Berhubung zaman sekarang ini penggunaan internet bukan lagi barang baru maka peningkatan kualitas pembelajaran juga dapat dilakukan dengan memanfaatkan internet sehingga proses pembelajaran disebut juga dengan pembelajaran berbasis e-learning. Merupakan sebuah terobosan baru dibidang pengajaran dan pembelajaran, karena mampu meminimalkan perbedaan cara mengajar dan materi, sehingga memberikan standar kulitas pembelajaran yang lebih konsisten. Sistem e-Learning adalah mutlak diperlukan untuk mengantisipasi perkembangan jaman dengan dukungan teknologi informasi dimana semua menuju ke era digital, baik mekanisme maupun konten.
\end{abstract}

Kata Kunci: Pembelajaran e-learning

\begin{abstract}
The development of information technology in recent years has developed at a very high rate, giving a significant impact on the field of education, thus sparking the birth of the idea of e-learning. To be able to obtain maximum results it is necessary to design an e-learning learning process. The purpose of this writing is the use of the e-learning model in improving the learning process so that it can improve adult learning outcomes. The research method used in the discussion of this paper is the literature study method. The learning model with e-learning is a new breakthrough in the field of teaching and learning, because it is able to minimize differences in teaching methods and materials, thus providing a more consistent quality standard of learning. The e-Learning system is absolutely necessary to anticipate the changing times with the support of information technology where everything is leading to the digital era, both mechanism and content. To be able to produce e-learning that is attractive and desirable in improving the quality of learning, there are three conditions that must be fulfilled in designing elearning, namely: Simple, simple systems that will make it easier for students to take advantage of existing technology and menus. Personally, teachers can interact well with students, such as communicating in front of the class. Fast, fast, fast response services to the complaints and needs of students, so that learning improvements can be carried out as quickly as possible by the teacher or manager.
\end{abstract}

Key Word: Pembelajaran e-learning

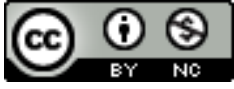

This work is licensed under a Creative Commons Attribution-NonCommercial 4.0 International License 


\section{PENDAHULUAN}

Perkembangan teknologi informasi beberapa tahun belakangan ini berkembang dengan kecepatan yang sangat tinggi, memberikan dampak yang cukup berarti pada bidang pendidikan, dimana pada dasarnya pendidikan merupakan suatu proses komunikasi dan informasi dari pendidik kepada peserta didik yang berisi informasi-informasi pendidikan, yang memiliki unsur-unsur pendidik sebagai sumber informasi, media sebagai sarana penyajian ide, gagasan dan materi pendidikan serta peserta didik itu sendiri (Oetomo dan Priyogutomo, 2004), beberapa bagian unsur ini mendapatkan sentuhan media teknologi informasi, sehingga mencetuskan lahirnya ide tentang e-learning (Utomo, 2001)

Skenario mengajar dan belajar perlu disiapkan secara matang dalam sebuah kurikulum pembelajaran yang memang dirancang berbasis internet. Mengimplementasikan pembelajaran berbasis internet bukan berarti sekedar meletakkan materi ajar pada web. Selain materi ajar, skenario pembelajaran perlu disiapkan dengan matang untuk mengundang keterlibatan peserta didik secara aktif dan konstruktif dalam proses belajar mereka.

Teknologi baru terutama dalam bidang ICT memiliki peran yang semakin penting dalam pembelajaran. Banyak orang percaya bahwa multimedia akan dapat membawa kita kepada situasi belajar dimana "learning with effort" akan dapat digantikan dengan "learning with fun". Apalagi dalam pembelajaran orang dewasa, learning with effort menjadi hal yang cukup menyulitkan untuk dilaksanakan karena berbagai faktor pembatas seperti usia, kemampuan daya tangkap, kemauan berusaha, dll. Jadi proses pembelajaran yang menyenangkan, kreatif, tidak membosankan menjadi pilihan para fasilitator. Jika situasi belajar seperti ini tidak tercipta, paling tidak multimedia dapat membuat belajar lebih efektif menurut pendapat beberapa pengajar. Pada saat ini kita semua memahami bahwa "proses belajar" dipandang sebagai proses yang aktif dan partisipatif, konstruktif, kumulatif, dan berorientasi pada tujuan pembelajaran,

Mengkombinasikan antara pertemuan secara tatap muka dengan pembelajaran elektronik dapat meningkatkan kontribusi dan interaktifitas antar peserta didik. Melalui tatap muka peserta didik dapat mengenal sesama peserta didik dan guru pendampingnya. Keakraban ini sangat menunjang kerja kolaborasi mereka secara virtual. Persiapan matang sebelum mengimplementasikan sebuah pembelajaran berbasis multimedia memegang peran penting demi kelancaran proses pembelajaran. Segala persiapan seperti penjadwalan sampai dengan penentuan teknis komunikasi selama proses pembelajaran merupakan tahapan penting dalam melaksanakan pembelajaran berbasis web. Oleh karena itu makalah ini akan membahas penggunaan model pembelajaran elearning dalam meningkat proses pembelajaran.

\section{METODE PENELITIAN}

Metode yang digunakan dalam makalah ini adalah studi kepustakaaan.

\section{TEMUAN DAN PEMBAHASAN}

1. TEMUAN

2. PEMBAHASAN

\section{E-learning Sebagai Media Pembelajaran}

E-Learning adalah pembelajaran jarak jauh (distance Learning) yang memanfaatkan teknologi komputer, jaringan komputer dan/atau Internet. ELearning memungkinkan pembelajar untuk belajar melalui komputer di tempat mereka masing-masing tanpa harus secara fisik pergi mengikuti pelajaran/perkuliahan di kelas. E-Learning sering pula dipahami sebagai suatu bentuk pembelajaran berbasis web yang bisa diakses dari intranet di jaringan lokal atau internet. Pembelajaran dengan menggunakan media 
elektronik dalam bentuk E-learning disampaikan dengan menggunakan media elektronik yang terhubung dengan Internet dan Intranet.

Dengan cara ini, jumlah pembelajar yang bisa ikut berpartisipasi bisa jauh lebih besar dari pada cara belajar secara konvensional di ruang kelas (jumlah siswa tidak terbatas pada besarnya ruang kelas). Teknologi ini juga memungkinkan penyampaian pelajaran dengan kualitas yang relatif lebih standar dari pada pembelajaran di kelas yang tergantung pada "mood" dan kondisi fisik dari instruktur. Dalam e-learning, modul-modul yang sama (informasi, penampilan, dan kualitas pembelajaran) bisa diakses dalam bentuk yang sama oleh semua siswa yang mengaksesnya, sedangkan dalam pembelajaran konvensional di kelas, karena alasan kesehatan atau masalah pribadi, satu instruktur pun bisa memberikan pelajaran di beberapa kelas dengan kualitas yang berbeda.

Pembelajaran formal vs. informal. E-learning dalam arti luas bisa mencakup pembelajaran yang dilakukan di media elektronik (internet) baik secara formal maupun informal. E-learning secara formal, misalnya adalah pembelajaran dengan kurikulum, silabus, mata pelajaran dan tes yang telah diatur dan disusun berdasarkan jadwal yang telah disepakati pihak-pihak terkait (pengelola e-learning dan pembelajar sendiri).

Pembelajaran seperti ini biasanya tingkat interaksinya tinggi dan diwajibkan oleh perusahaan pada karyawannya, atau pembelajaran jarak jauh yang dikelola oleh universitas dan perusahaan-perusahaan (biasanya perusahan konsultan) yang memang bergerak di bidang penyediaan jasa e-learning untuk umum. E-learning bisa juga dilakukan secara informal dengan interaksi yang lebih sederhana, misalnya melalui sarana mailing list, e-newsletter atau website pribadi, organisasi dan perusahaan yang ingin mensosialisasikan jasa, program, pengetahuan atau keterampilan tertentu pada masyarakat luas (biasanya tanpa memungut biaya).
Beberapa manfaat yang bisa dinikmati dari proses pembelajaran dengan e-learning, diataranya :

1. Fleksibilitas.

Jika pembelajaran konvensional di kelas mengharuskan siswa untuk hadir di kelas pada jam-jam tertentu (seringkali jam ini bentrok dengan kegiatan rutin siswa), maka elearning memberikan fleksibilitas dalam memilih waktu dan tempat untuk mengakses pelajaran.

2. Independent Learning

E-learning memberikan kesempatan bagi pembelajar untuk memegang kendali atas kesuksesan belajar masing-masing, artinya pembelajar diberi kebebasan untuk menentukan kapan akan mulai, kapan akan menyelesaikan, dan bagian mana dalam satu modul yang ingin dipelajarinya terlebih dulu.

3. Biaya

Banyak biaya yang bisa dihemat dari cara pembelajaran dengan e-learning. Biaya di sini tidak hanya dari segi finansial tetapi juga dari segi non-finansial.

Pada dasarnya cara penyampaian atau cara pemberian (delivery system) dar e-learning, dapat digolongkan menjadi dua yaitu : komunikasi satu arah dan komunikasi dua arah. Komunikasi atau interaksi antara dosen dan mahasiswa memang sebaiknya melalui sistem dua arah. Dalam e-learning, sistem dua arah ini juga bisa diklasifikasikan menjadi dua, yaitu :

a. Dilaksanakan melalui cara langsung artinya pada saat instruktur memberikan materi kuliah, peserta didik dapat langsung mendengarkanya.

b. Dilaksanakan melalui cara tidak langsung misalnya pesan dari instruktur direkam dahulu sebelum digunakan.

Pemanfaatan e-learning tidak terlepas dari jasa internet, karena teknik pembelajaran yang tersedia di internet begitu lengkap, dan hal ini akan mempengaruhi tugas pengajar dalam proses pembelajaran. Dahulu, proses belajar mengajar dominasi oleh peran pendidik, karena itu disebut the era of teacher. Kini, proses belajar dan mengajar, banyak dido 
minsi oleh peran pendidik dan buku (the era of teacher and book) dan pada masa mendatang prose belajar mengajar akan didominasi oleh peran pendidik, buku dan teknologi (the era of teacher, book and technology).

Pengembangan e-learning tidak semata-mata hanya menyajikan materi pelajaran secar online saja, namun harus komunikatif dan menarik. Materi pembelajaran didesain seolah peserta didik belajar dihadapan pengajar memalui layar komputer yang dihubungkan melalui jaringan internet.

Untuk dapat menghasilkan elearning yang menarik dan diminati dalam meningkatkan kualitas pembelajaran, ada tiga syarat hal yang wajib dipenuhi dalam merancang e-learning, yaitu :

1. Sederhana, sistem yang sederhana akan memudahkan peserta didik dalam memanfaatkan teknologi dan menu yang ada, dengan kemudahan pada panel yang disediakan, waktu belajar peserta akan lebih efisien.

2. Personal, pengajar dapat berinteraksi baik dengan pelajar, seperti layaknya berkomunikasi di depan kelas.

3. Cepat, layanan yang ditunjang dengan kecepatan, respon yang cepat terhadap keluhan dan kebutuhan peserta didik, sehingga perbaikan pembelajaran dapat dilakukan secepat mungkin oleh pengajar atau pengelola.

E-learning perlu diciptakan seolaholah peserta didik belajar secara konvensional, hanya saja dipindahkan kedalam sistem digital melalui internet. Karena itu e-learning perlu mengadaptasi unsur-unsur yang biasa dilakukan dalam sistem pembelajaran konvensional. Misalnya dimulai darai perumusan tujuan operasional dan dapat diukur, ada apersepsi atau pre test, membangkitkan motivasi, menggunakan bahasa yang komunikatif, uraian materi yang jelas, contoh-contoh konkrit, problem solving, Tanya jawab, diskusi, post test, sampai penugasan dan kegiatan tindak lanjutnya. Oleh karena itu merancang e-learning perlu melibatkan pihak terkait, antara lain : pengajar, ahli materi, ahli komunikasi, programmer, seniman dan lain-lain.

Keunggulan dan Kekurangan E-Learning

Petunjuk tentang manfaat penggunaan internet, khususnya dalam pendidikan terbuka dan jarak jauh (Elangoan, 1999; Soekartawi, 2002; Mulvihil, 1997; Utarini, 1997), antara lain. Pertama, Tersedianya fasilitas emoderating di mana pengajar dan pelajar dapat berkomunikasi secara mudah melalui fasilitas internet secara regular atau kapan saja kegiatan berkomunikasi itu dilakukan dengan tanpa dibatasi oleh jarak, tempat dan waktu. Kedua, pengajar dan pelajar dapat menggunakan bahan ajar atau petunjuk belajar yang terstruktur dan terjadual melalui internet, sehingga keduanya bisa saling menilai sampai berapa jauh bahan ajar dipelajari. Ketiga, Pelajar dapat belajar atau me-review bahan ajar (mata kuliaha) setiap saat dan di mana saja kalau diperlukan mengingat bahan ajar tersimpan di komputer. Keempat, Bila pelajar memerlukan tambahan informasi yang berkaitan dengan bahan yang dipelajarinya, ia dapat melakukan akses di internet secara lebih mudah. Kelima, Baik pengajar maupun pelajar dapat melakukan diskusi melalui internet yang dapat diikuti dengan jumlah peserta yang banyak, sehingga menambah ilmu pengetahuan dan wawasan yang lebih luas. Keenam,Berubahnya peran pelajar dari yang biasanya pasif menjadi aktif. Ketujuh, Relatif lebih efisien. Misalnya bagi mereka yang tinggal jauh dari perguruan tinggi atau sekolah konvensional.Walaupun demikian pemanfaatan internet untuk pembelajaran atau e-learning juga tidak terlepas dari berbagai kekurangan. Berbagai kritik (Bullen, 2001, Beam, 1997), antara lain. Pertama, Kurangnya interaksi antara pengajar dan pelajar atau bahkan antar pelajar itu sendiri. Kurangnya interaksi ini bisa memperlambat terbentuknya values dalam proses belajar dan mengajar. Kedua, Kecenderungan mengabaikan aspek akademik atau aspek sosial dan sebaliknya mendorong tumbuhnya aspek bisnis/komersial. Ketiga, Proses belajar dan 
mengajarnya cenderung ke arah pelatihan daripada pendidikan. Keempat, Berubahnya peran guru dari yang semula menguasai teknik pembelajaran konvensional, kini juga dituntut mengetahui teknik pembelajaran yang menggunakan ICT. Kelima, Siswa yang tidak mempunyai motivasi belajar yang tinggi cenderung gagal. Keenam, Tidak semua tempat tersedia fasilitas internet. Ketujuh, Kurangnya tenaga yang mengetahui dan memiliki ketrampilan internet. Kedelapan, Kurangnya penguasaan bahasa komputer.

\section{PENUTUP}

Model pembelajaran dengan elearning merupakan sebuah terobosan baru dibidang pengajaran dan pembelajaran, karena mampu meminimalkan perbedaan cara mengajar dan materi, sehingga memberikan standar kulitas pembelajaran yang lebih konsisten. Sistem e-Learning adalah mutlak diperlukan untuk mengantisipasi perkembangan jaman dengan dukungan teknologi informasi dimana semua menuju ke era digital, baik mekanisme maupun konten. 


\section{DAFTAR PUSTAKA}

Djamarah, Syaiful B dan Zain, Aswan. (2002). Strategi Belajar Mengajar. Jakarta : Rineka Cipta. Hamalik, O. (1986). Media Pendidikan. Bandung : Penerbit Alumni.

Kamarga, Hanny. (2002). Belajar Sejarah melalui e-learning; Alternatif Mengakses Sumber Informasi Kesejarahan. Jakarta: Inti Media.

Syah, Muhibbin. (2002). Psikologi Pendidikan dengan Pendekatan Baru. Bandung : Rosda Karya.

Soekarwati. (2000). Prospek Pembelajaran Melalui Internet, Makalah Seminar Teknologi Kependidikan, UT Pustekkom dan IPTPI, Jakarta.

Soekartawi. (2003). Prinsip Dasar E-Learning: Teori dan Aplikasinya di Indonesia, Jurnal Teknodik, Edisi No.12/VII/Oktober/ 2003.

Utomo, Junaidi. (2001). Dampak Internet Terhadap Pendidikan : Transformasi atau Evolusi, Seminar Nasional Universitas Atma Jaya Yogyakarta. 